\title{
Cytotoxic Potential of Flavonoid from Nicotiana tabacum Leaves on MCF-7 Human Breast Cancer Cells
}

\author{
Banun Kusumawardani ${ }^{1 *}$, Qonita Nafilah Febi $^{2}$, Malihatul Rosidah ${ }^{2}$, \\ Deri Abdul Azis ${ }^{2}$, Endah Puspitasari ${ }^{3}$, Ari Satia Nugraha ${ }^{4}$
}

\author{
${ }^{1}$ Department of Biomedical Sciences, Faculty of Dentistry, University of Jember, Jember, Indonesia \\ ${ }^{2}$ Undergraduate Program, Faculty of Dentistry, University of Jember, Jember, Indonesia \\ ${ }^{3}$ Department of Pharmaceutical Biology, Faculty of Pharmacy, University of Jember, Jember, Indonesia \\ ${ }^{4}$ Drug Utilization and Discovery Research Group, Faculty of Pharmacy, University of Jember, Jember, Indonesia
}

\begin{abstract}
Flavonoid has potential bioactivity as anticancer agents. The flavonoid of cultivated tobacco (Nicotiana tabacum), locally known as "Kasturi", leaves was screened for its cytotoxicity against MCF-7 human breast cancer cells and non-transformed Vero cells (African normal cell kidney line) in different concentrations. This study aimed to examine the cytotoxic potential of the flavonoid of Kasturi tobacco leaves against MCF-7 human breast cancer cells. Flavonoid obtained from methanolic extracts of Kasturi tobacco leaves, which have been purified from nicotine. The flavonoid of Kasturi tobacco leaves with concentrations of 20 to $640 \mu \mathrm{g} / \mathrm{mL}$ were exposed to MCF-7 and Vero cells for $24 \mathrm{~h}$. Cell viability was evaluated by 3-(4,5-dimethyl-2-thiazolyl)-2,5-diphenyl-2H-tetrazolium bromide (MTT) assay. Flavonoid of Kasturi tobacco leaves with concentrations of $160 \mu \mathrm{g} / \mathrm{mL}$ decreased the MCF-7 cell viability more than $50 \%$, with an inhibitory concentration $50\left(\mathrm{IC}_{50}\right)$ value of $148.41 \mu \mathrm{g} / \mathrm{mL}$. Meanwhile, it inhibited $50 \%$ of Vero cell viability at $255.35 \mu \mathrm{g} / \mathrm{mL}$. The flavonoid of Kasturi tobacco leaves has cytotoxic activity on MCF-7 cells, and might be a potential alternative agent for human breast cancer therapy.
\end{abstract}

Keywords: flavonoid, tobacco leaves, human breast cancer cells, anticancer activity.

\section{INTRODUCTION}

Cultivated tobacco, locally known as Kasturi tobacco, (Nicotiana tabacum) is local tobacco Voor Oogst, which is planted in Jember and Bondowoso areas. Kasturi tobacco is intended as raw material for domestic cigarettes, which reaches $88.64 \%$ and around $11.36 \%$ is exported. In addition to extensive use of cigarette products, tobacco leaves are a rich source of many biologically active substances with pharmacological properties. Many researchers have made efforts to diversify tobacco products, starting with determination of total phenolic and total flavonoid from tobacco leaves (Fathiazad, et al., 2006; Xie, et al., 2011; Karabegović, et al., 2011), and analysis the antioxidant activity of purified flavonoid from nicotine and phenolic acid (Docheva, et al., 2014). On the other hand, it is known that flavonoid have various anticancer phytochemicals with potential bioactivity that can reduce cancer susceptibility,

Submitted: April 28, 2019

Revised: July 20, 2020

Accepted: July 20, 2020

*Corresponding author: banun_k.fkg@unej.ac.id 
and can be candidates for cancer prevention (Yang, et al., 2001; Le Marchand, 2002).

Breast cancer is the second most common malignant tumor in the world and causes cancerrelated deaths after lung cancer. Unfortunately, the overall response rate of cancer treatment is unsatisfactory because of the late diagnosis and efficacy of poor treatment, especially resistance to chemotherapy drugs and metastasis to other organs (Metwaly, et al., 2012). In addition, many chemotherapy drugs reduce the therapeutic effect due to drug resistance problems (Peters, et al., 2002). Chemotherapy drugs also cause toxicity to normal cell, and unpleasant side effects for patients. For this reason, it takes research and development of a new class of anticancer agents that have selective and efficient toxicity in cells. Among various sources of anticancer drugs, the use of natural resources from plants has many benefits about the potential to produce a variety of anticancer agents. In this study, we aimed to find a new source of natural anticancer isolated from Kasturi tobacco leaves and investigate the cytotoxicity ability of the flavonoid of Kasturi tobacco leaves against MCF-7 and Vero cells.

\section{MATERIALS AND METHODS}

\section{Kasturi tobacco Leaves Extraction}

Dried Kasturi tobacco leaves (50 g) were ground and sieved until tobacco leaf powder is obtained. Tobacco leaves powder were macerated 3 times with methanol (Merck, Darmstadt, Germany) and stirred for $24 \mathrm{~h}$ to bind compounds in tobacco leaves (Hossain \& Salehuddin, 2013), then were filtered using a Buchner funnel. The filtrate was fractionated by liquid-liquid extraction using ethyl acetate (Merck) (Mujwah, et al., 2010), and separated between the methanol and ethyl acetate phases with a separating funnel. The ethyl acetate phase was added with $10 \% \mathrm{HCl}$ (Merck) to remove the nicotine (alkaloid) content and was tested with Dragendorff reagent (ACS Chemicals, Gujarat, India). The extract will be yellow if it is free of nicotine and will be orange if it still contains nicotine. Extract was evaporated using a rotary evaporator until a thick extract is obtained. The extract was weighed $1.216 \mathrm{~g}$, with a yield of $2.432 \%$.

\section{Total Phenolic in Kasturi tobacco Leaves Extract}

The extract was dissolved with methanol (Merck) in a concentration of $1 \mathrm{mg} / \mathrm{mL}$. The reaction mixture was made with a composition of $0.5 \mathrm{~mL}$ of extracted methanol solution, $2.5 \mathrm{~mL}$ of 10\% Folin-Ciocalteu reagent (Sigma-Aldrich, St. Louis, Missouri, USA) that has been dissolved in water and $2.5 \mathrm{~mL}$ of $7.5 \% \mathrm{NaHCO}_{3}$ (Merck). The blank was made with a composition of $0.5 \mathrm{~mL}$ of methanol (Merck), $2.5 \mathrm{~mL}$ of 10\% Folin-Ciocalteu reagent (Sigma-Aldrich) dissolved in water and $2.5 \mathrm{~mL}$ of $7.5 \% \mathrm{NaHCO}_{3}$ (Merck). The sample was incubated at $45^{\circ} \mathrm{C}$ for 45 minutes. Absorbance was determined using a spectrophotometer at $\lambda \max =765$ $\mathrm{nm}$ and carried out in triplicate for each analysis. The same procedure was repeated for standard gallic acid solution (Sigma-Aldrich) as a calibration curve (Stanković, 2011). Based on the absorbance measured, the phenolic concentration is read (mg/ $\mathrm{mL}$ ) from the calibration line; then the phenolic content in the extract is expressed in the form of gallic acid equivalent (mg GA/g extract). The phenolic content in Kasturi tobacco leaves extract was $0.878 \mathrm{mg} / \mathrm{g}$.

\section{Cell Line and Culture Condition}

Human breast cancer cells (MCF-7) and normal African green monkey kidney epithelial (Vero) cell lines were maintained at the Laboratory of Parasitology, Faculty of Medicine, Universitas Gadjah Mada, Indonesia. The cell culture medium was Dulbecco's modified Eagle's medium (DMEM) (Gibco, Canada, USA) supplemented with 10\% fetal bovine serum (FBS) (Gibco, Brazil, USA), 100 units $/ \mathrm{mL}$ penicillin and $100 \mu \mathrm{g} / \mathrm{mL}$ streptomycin (Gibco, Germany). The cells were cultured at $37^{\circ} \mathrm{C}$ under a humidified atmosphere containing $5 \% \mathrm{CO}_{2}$. 
Cytotoxicity Screening by 3-(4, 5-dimethyl2-thiazolyl)-2, 5-diphenyl-2H-tetrazolium bromide (MTT) Assay

Cytotoxicity of flavonoid was determined by MTT assay. Briefly, MCF-7 and Vero cells were seeded into 96-well plates (5000 cells/well in $100 \mu \mathrm{L}$ of media) and incubated for $24 \mathrm{~h}$. Prior to the experiment, the stock solution of flavonoid was prepared by dissolving in dimethyl sulfoxide (DMSO) (Sigma-Aldrich) and diluted to working solutions with media serially to obtain appropriate concentrations. The final concentration of DMSO (Sigma-Aldrich) in each sample did not exceed $1 \% \mathrm{v} / \mathrm{v}$. Cells were treated with the flavonoid at concentrations of $20,40,80,160,320$, and 640 $\mu \mathrm{g} / \mathrm{mL}$ and incubated for $24 \mathrm{~h}$. MCF-7 and Vero cells in positive control group were treated with doxorubicin (Sigma-Aldrich). The medium from each well was removed carefully after incubation. Two hundred microliters of MTT solution $(5 \mathrm{mg} /$ $\mathrm{mL}$ ) (Sigma-Aldrich) was added. The plates were incubated for $4 \mathrm{~h}$ in dark. After incubation, MTT solution was removed without disturbing the formazan crystals and $100 \mu \mathrm{L}$ of DMSO (SigmaAldrich) was added to each well and mixed well to dissolve the crystals properly. The development of purple color due to formation of formazan crystals visualized the viable cells. The absorbance was measured on microplate reader at $570 \mathrm{~nm}$. The inhibitory concentration $50\left(\mathrm{IC}_{50}\right)$ values were determined from the graphs of flavonoid on MCF7 and Vero cells. The cell viability percentage was calculated based on the absorbance ratio between cell culture treated with flavonoid and the untreated control multiplied by $100 \%$ (Wang, et al., 2006). Experiment was repeated three times independently, and each with triplicate sets of reaction.

\section{Statistical analysis}

The mean values \pm standard deviation of three independent experiments was used for quantitative variables. Statistical significance was ascertained by one-way ANOVA, followed by Tukey's post hoc test of significance between different groups. Statistical significance was predefined as $P \leq 0.05$.

\section{RESULTS}

The flavonoid of Kasturi tobacco leave was tested to evaluate the cytotoxic potential against the human breast cancer cells. The MTT assay showed remarkable cytotoxicity against MCF-7 cells in a dose dependent manner. The flavonoid started to show cytotoxicity on Vero cells at concentrations of $320 \mu \mathrm{g} / \mathrm{mL}$ and the calculated $\mathrm{IC}_{50}$ was obtained at $255.35 \mu \mathrm{g} / \mathrm{mL}$. The cell viability count to determine anticancer activity against MCF-7 and Vero cells is represented in Table 1 and Figure 1. The anticancer activity of flavonoid against MCF-7 cell lines showed higher cytotoxicity at concentrations of 160,320 , and $640 \mu \mathrm{g} / \mathrm{mL}$, with an $\mathrm{IC}_{50}$ of 148.41 $\mu \mathrm{g} / \mathrm{mL}$. These data suggested that the extracts are more toxic to cancer cells than normal cells. Nevertheless, flavonoid was not as active as doxorubicin. Doxorubicin with concentration of $0.8 \mu \mathrm{g} / \mathrm{mL}$ can decrease cell viability of MCF-7 and Vero cells about $65.28 \pm 7.20 \%$ and $58.92 \pm 6.90 \%$, respectively.

\section{DISCUSSION}

Cancer chemoprevention by using natural ingredients in the form of dietary or synthetic substances can reverse, suppress, or prevent carcinogenic development. This strategy is very interesting to combat the dogma associated with increasing cases of cancer throughout the world (Tsao, et al., 2004). Plant extracts that act as anticancer drugs must be able to kill cancer cells without causing excessive damage to normal cells (Lacroix, et al., 2006). Flavonoids are plant pigments consisting of natural phytochemical classes, and have various biological effects that can play a role in cancer prevention and cancer therapy. Increased anticancer activity correlates with an increase in the number of polyphenolic compounds (Danciu, et al., 2015). Quercetin, a member of flavonol, is reported 
Indonesian Journal of Cancer Chemoprevention, June 2020

ISSN: 2088-0197

e-ISSN: $2355-8989$

Table 1. Effect of flavonoid of Kasturi tobacco leaves on cell viability of MCF-7 and Vero cells by MTT assay.

\begin{tabular}{lccc}
\hline \multirow{2}{*}{$\begin{array}{c}\text { Concentration } \\
(\mu \mathrm{g} / \mathrm{mL})\end{array}$} & \multicolumn{2}{c}{ Cell Viability (\%) } & \multirow{2}{*}{$P$ Value } \\
\cline { 2 - 3 } & Vero Cell Line & MCF-7 Cell Line & \\
\hline Flavonoid 640 & $6.98 \pm 2.03$ & $1.54 \pm 0.77$ & 0.56 \\
Flavonoid 320 & $38.26 \pm 19.04$ & $2.32 \pm 1.54$ & 0.00 \\
Flavonoid 160 & $93.52 \pm 17.54$ & $39.77 \pm 27.27$ & 0.00 \\
Flavonoid 80 & $98.92 \pm 14.77$ & $96.05 \pm 16.30$ & 0.76 \\
Flavonoid 40 & $105.33 \pm 8.67$ & $101.51 \pm 14.90$ & 0.68 \\
Flavonoid 20 & $112.18 \pm 19.59$ & $93.69 \pm 7.91$ & 0.05 \\
Doxorubicin 0.8 & $58.92 \pm 6.90$ & $65.28 \pm 7.20$ & 0.50
\end{tabular}

aMean \pm standard deviation of three independent experiments; ${ }^{b}$ normal cells; ${ }^{c}$ cancer cells. Data were analyzed using one-way ANOVA and followed by Tukey's post hoc test $(P \leq 0.05)$.

as an attractive anticancer agent against breast cancer (Brusselmans, et al., 2005; Du, et al., 2010; Hashemzaei, et al., 2017). The antioxidant activity of quercetin is believed to have a cytoprotective role against oxidative stress. Quercetin is not only protecting cells from free radical damage through antioxidant effects, but also motivates apoptotic cell death through pro-oxidant activity and inhibits tumorigenesis (Gibellini, et al., 2010).

MCF-7 cells are estrogen-receptor (ER) positive and are classified as low-grade and luminal types (Kenny, et al., 2007). Our results showed that the flavonoid of Kasturi tobacco leaves has more cytotoxic effects on MCF-7 than Vero cells (Table 1 and Figure 1). These results indicated that our extract is more selective for breast cancer cells than normal cells. Flavonoid of Kasturi tobacco leaves can be considered as potential chemotherapy or chemopreventive agent based on its ability to induce apoptosis in cancer cells with relatively low toxicity to normal cells. The $\mathrm{IC}_{50}$ value of the flavonoid of Kasturi tobacco leaves $(148.41 \mu \mathrm{g} / \mathrm{mL})$ was found to be more efficient for anti-breast cancer cell activity. Therefore, anticancer strength may be related to quercetin content in our extract, which quercetin can induce cytotoxicity in the cancer cell line through various routes of action. Quercetin can induce DNA damage, which needs to be repaired before cell division occurs, and induces cytotoxicity by activating the intrinsic pathway of apoptosis (Srivastava, et al., 2016). This confirms our assumption that the flavonoid can be responsible for the anticancer activity of Kasturi tobacco leaves.

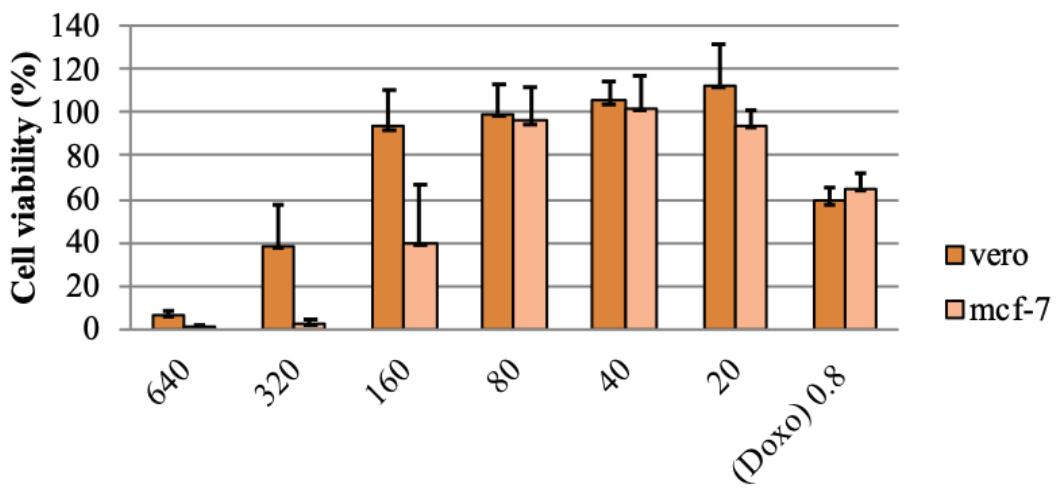

Concentration of flavonoid $(\mu \mathrm{g} / \mathrm{ml})$

Figure 1. Cytotoxic potential of flavonoid from Kasturi tobacco leaves on MCF-7 and Vero cells. Error bar represents mean \pm standard deviation of experiments performed in three repetitions. 


\section{CONCLUSION}

Viability of breast cancer cells will decrease according to dependent-dose. The flavonoid of Kasturi tobacco leaves proved to be able to reduce $50 \%$ viability of breast cancer cells at a concentration of $148.41 \mu \mathrm{g} / \mathrm{mL}$. The MTT assay showed remarkable cytotoxicity against MCF-7 cell. This flavonoid could be developed as an alternative chemopreventive agent, however further research should be pursued.

\section{ACKNOWLEDGMENT}

This work was partly supported by a "Program Kreativitas Mahasiswa" grant (827/SPK/ KM.02.01/2019) from the Ministry of Research, Technology and Higher Education of Indonesia.

\section{AUTHORS' STATEMENT}

The authors declare that they have no potential conflict of interest regarding submission and publication of this manuscript.

\section{REFERENCES}

Brusselmans, K., Vrolix, R., Verhoeven, G. and Swinnen, J.V., 2002, Induction of cancer cell apoptosis by flavonoids is associated with their ability to inhibit fatty acid synthase activity, J. Biol. Chem., 280(7), 5636-5645.

Danciu, C., Vlaia, L., Fetea, F., Hancianu, M., Coricovac, D.E., et al., 2015, Evaluation of phenolic profile, antioxidant and anticancer potential of two main representants of Zingiberaceae family against B164A5 murine melanoma cells, Biol. Res., 48, 1.

Docheva, M., Dagnon, S. and Statkova-Abeghe, S., 2014, Flavonoid content and radical scavenging potential of extracts prepared from tobacco culvitars and waste, Nat. Prod. Res., 28(17), 1328-1334.
Du, G., Lin, H., Wang, M., Zhang, S., Wu, X., et al., 2010, Quercetin greatly improved therapeutic index of doxorubicin against 4T1 breast cancer by its opposing effects on HIF-1 $\square$ in tumor and normal cells, Cancer Chemother. Pharmacol, 65(2), 277-287.

Fathiazad, F., Delazar, A., Amiri, R. and Sarker, S.D., 2006, Extraction of flavonoids and quantification of rutin from waste tobacco leaves, IJPR., 5(3), 222-227.

Gibellini, L., Pinti, M., Nasi, M., De Biasi, S., Roat, E., et al., 2010, Interfering with ROS metabolism in cancer cells: the potential role of quercetin, Cancers, 2(2), 1288-1311.

Hashemzaei, M., Far, A.D., Yari, A., Heravi, R.E., Tabrizian, K., et al., 2017, Anticancer and apoptosis-inducing effects of quercetin in vitro and in vivo, Oncol. Rep., 38(2), 819-828.

Hossain, M. and Salehuddin, S., 2013, Analytical determination of nicotine in tobacco leaves by gas chromatography-mass spectrometry, Arabian Journal of Chemistry, 6, 275-278.

Karabegović, I.T., Veljković, V.B. and Lazić M.L., 2011, Ultrasound-assisted extraction of total phenols and flavonoids from dry tobacco (Nicotiana tabacum) leaves, Nat. Prod. Commun., 6(12), 1855-1856.

Kenny, P.A., Lee, G.Y., Myers, C.A., Neve, R.M., Semeiks, J.R., et al., 2007, The morphologies of breast cancer cell lines in three-dimensional assays correlate with their profiles of gene expression, Mol. Oncol., 1(1), 84-96.

Lacroix, M., Toillon, R.A. and Leclercq, G, 2006, p53 and breast cancer, an update. Endocr. Relat. Cancer, 13(2), 293-325.

Le Marchand, L., 2002, Cancer preventive effects of flavonoids-a review, Biomed. Pharmacother., 56(6), 296-301.

Metwaly, H.A., Al-Gayyar, M.M., Eletreby, S., Ebrahim, M.A. and El-Shishtawy, M.M., 2012, Relevance of serum levels of interleukin- 6 and syndecan-1 in patients with hepatocellular carcinoma, Sci. Pharm., 80(1), 179-188. 
Mujwah, A., Mohammed, M. and Ahmed, M., 2010. First isolation of a flavonoid fom Juniperus procera using ethyl acetate extract, Arabian Journal of Chemistry, 3, 85-88.

Peters, G.J., Backus, H.H., Freemantle, S., van Triest, B., Codacci-Pisanelli, G., et al., 2002, Induction of thymidylate synthase as a 5-fluorouracil resistance mechanism, Biochim. Biophys. Acta., 1587(2-3), 194-205.

Srivastava, S., Somasagara, R.R., Hegde, M., Nishana, M., Tadi, S.K., et al., 2016, Quercetin, a natural flavonoid interacts with dna, arrests cell cycle and causes tumor regression by activating mitochondrial pathway of apoptosis, Sci. Rep., 6, 24049.

Stankovic, M., 2011, Total phenolic content, flavonoid concentration and antioxidant activity of Mar- rubium peregrinum L, Extracts, 33, 63-72.

Tsao, A.S., Edward, S.K. and Hong, W.K., 2004, Chemoprevention of cancer, C.A. Cancer J. Clin., 54(3), 150-180.

Wang, X., Yuan, S., Wang, J., Lin, P., Liu, G., et al., 2006, Anticancer activity of litchi fruit pericarp extract against human breast cancer in vitro and in vivo, Toxicol. Appl. Pharmacol., 215(2), 168-178.

Xie, F., Yu, A., Hou, D., Liu, H., Ding, L., et al., 2011, Rapid and sensitive analysis of eight polyphenols in tobacco by rapid resolution liquid chromatography, AJAC, 2(2), 929-933.

Yang, C.S., Landau, J.M., Huang, M.T. and Newmark, H.L., 2001, Inhibition of carcinogenesis by dietary polyphenolic compounds, Annu. Rev. Nutr., 21, 381-406. 